IZA DP No. 4391

The Redistributive Effects of Political

Reservation for Minorities: Evidence from India

Aimee Chin

Nishith Prakash

September 2009 


\title{
The Redistributive Effects of Political Reservation for Minorities: Evidence from India
}

\author{
Aimee Chin \\ University of Houston \\ Nishith Prakash \\ Dartmouth College \\ and IZA

\section{Discussion Paper No. 4391 \\ September 2009} \\ IZA \\ P.O. Box 7240 \\ 53072 Bonn \\ Germany \\ Phone: +49-228-3894-0 \\ Fax: +49-228-3894-180 \\ E-mail: iza@iza.org
}

Any opinions expressed here are those of the author(s) and not those of IZA. Research published in this series may include views on policy, but the institute itself takes no institutional policy positions.

The Institute for the Study of Labor (IZA) in Bonn is a local and virtual international research center and a place of communication between science, politics and business. IZA is an independent nonprofit organization supported by Deutsche Post Foundation. The center is associated with the University of Bonn and offers a stimulating research environment through its international network, workshops and conferences, data service, project support, research visits and doctoral program. IZA engages in (i) original and internationally competitive research in all fields of labor economics, (ii) development of policy concepts, and (iii) dissemination of research results and concepts to the interested public.

IZA Discussion Papers often represent preliminary work and are circulated to encourage discussion. Citation of such a paper should account for its provisional character. A revised version may be available directly from the author. 


\section{ABSTRACT}

\section{The Redistributive Effects of Political Reservation for Minorities: Evidence from India*}

We examine the impact of political reservation for disadvantaged minority groups on poverty. To address the concern that political reservation is endogenous in the relationship between poverty and reservation, we take advantage of the state-time variation in reservation in state legislative assemblies in India that arises from national policies that cause reservations to be revised and the time lags with which the revised reservations are implemented due to the timing of state elections. Using data on sixteen major Indian states for the period 1960-1992, we find that increasing the share of seats reserved for Scheduled Tribes significantly reduces poverty while increasing the share of seats reserved for Scheduled Castes has no impact on poverty. Political reservation for Scheduled Tribes has a greater effect on rural poverty than urban poverty, and appears to benefit people near the poverty line as well as those far below it.

JEL Classification: $\quad 138, \mathrm{~J} 15, \mathrm{~J} 78$

Keywords: $\quad$ affirmative action, poverty, minorities, India

Corresponding author:

Nishith Prakash

Department of Economics

Dartmouth College

305 Rockefeller Hall

Hanover, NH 03755

USA

E-mail: nishith.prakash@dartmouth.edu

\footnotetext{
* An earlier version of this paper circulated as "Does Political Reservation for Minorities Reduce Poverty? Evidence from India."

We thank Marianne Bertrand, Angus Chu, Steve Craig, Irma Clots-Figueras, Larry Howard, Chinhui Juhn, Steven Levitt, Tauhidur Rahman, and participants in the Fall 2006 University of Houston Department of Economics Graduate Workshop, 2007 Texas Econometrics Camp, and 2007 NEUDC Conference for helpful comments. Also, we thank officials at the Government of India Ministry of Social Justice and Empowerment and Scheduled Caste and Scheduled Tribe Commissioner's Office in New Delhi, India for data provision and discussion. We owe special thanks to Rohini Pande for sharing the data used in her paper on Indian political reservation for minorities and policy outcomes and providing comments. Financial support from the University of Houston, Department of Economics to collect data in India in Summer 2006 is gratefully acknowledged. We are responsible for any errors that may remain.
} 


\section{Introduction}

Many countries have affirmative action policies, which give preferential treatment to historically disadvantaged minority groups. These policies are extremely controversial. One set of issues relates to whether these policies benefit the intended beneficiaries. Do the policies actually improve the socioeconomic outcomes of the minority groups? Which members of the minority groups benefit? A second set of issues relates to the redistributive nature of affirmative action policies. If minority groups are given preferential treatment, then aren't non-minority groups made worse off? To the extent that affirmative action policies confer few or no benefits to minority groups and hurt members of non-minority groups, then society might be worse off with such policies. While there is some empirical work on the effect of affirmative action on the intended beneficiaries, there is little that quantifies its overall effects (a brief review of the related literature is provided in Section 2). This paper takes a step forward by examining the effect of one type of affirmative action, political reservation, on overall poverty in India. To our knowledge, this is the first paper that estimates the impact of an affirmative action policy on poverty.

Poverty is a relevant outcome to study. First, poverty reduction is a major objective of public policy, especially in developing countries. Second, poverty rates are a tangible and frequently used measure of well-being. It remains an open question whether affirmative action successfully reduces poverty. It is expected to, given that historically disadvantaged minority groups account for a disproportionate share of the poor. However, if the benefits accrue only to the relatively well off members of minority groups and hurt the less well off members of non-minority groups, affirmative action can increase overall poverty!

India accounts for one-third of the world's poor, with about two-fifths of its population living below the international poverty line of $\$ 1.25$ per day [Chen and Ravallion (2008)]. It also has the largest and among the most aggressive affirmative action programs in the world, with seats explicitly set aside for members of minority groups (i.e., the Scheduled 
Castes (SCs) and Scheduled Tribes (STs)) in higher education, public sector employment and political representation. Obviously these affirmative action programs, though in place for over 60 years, have not been sufficient to eliminate poverty. However, India's poverty rate has declined rapidly over this time period-between 1981 and 2005 alone, it declined from $60 \%$ of the population living below $\$ 1.25$ per day to $42 \%$-and it is of interest to understand the extent to which affirmation action contributed to this decline.

In general, regressing the outcome of interest on the measure of the affirmation action policy will not give the causal effect of the policy. This is because the policy variable is likely to be endogenous. For example, places where more minorities get elected may differ from places where fewer minorities get elected in ways that also affect the outcome, such as in their attitude toward minorities or level of development. Fortunately in the case of political reservations for minorities in India, there are institutional features that can be exploited to identify the causal effect of minority political representation. In particular, variation in minority political representation in the state legislative assembly arises from changes in the minority share of the population as measured by the census (the Indian Constitution calls for the share of seats reserved for SCs and STs in the each state to equal to their share of the state population in the most recently enumerated decennial census) and the timing of elections (with shares from a new census not taking effect until a state's first election following the census). We use this within-state cross-time variation in share of seats reserved for minorities to identify the effect of minority representation on poverty. We elaborate on this empirical strategy, which originated in Pande (2003), in Section 3.

We implement this empirical strategy using state panel data on sixteen Indian states for the period 1960-1992 (we describe these data in Section 4). In Section 5, we present the estimation results and robustness checks. Our main finding is that increasing the share of seats reserved for minorities reduces overall poverty. It does not appear that political reservation for minorities cause more members of non-minority groups to enter poverty than the number of members of minority groups exiting poverty. That is, though political reservation 
has some redistributive elements, at least it is not the less well off among the non-minority groups who bear the cost. We conclude in Section 6 .

\section{Background}

\section{$2.1 \quad$ Related Literature}

This study adds to the large literature on affirmative action (see Holzer and Neumark (2000) for a review, though it is focused on the United States context), including a rapidly growing one in the Indian context. In this subsection, we briefly discuss the empirical studies in the Indian context.

Galanter (1984) provides a rich analysis of the various affirmative action policies (in employment, education and political representation) for the SCs and STs, but does not quantify their effects. ${ }^{1}$ More recently, a number of papers have estimated the impact of political reservation (Duflo (2005) offers a review). Some institutional features of India's political reservation policy enable researchers to convincingly identify its effects. Pande (2003) takes advantage of the time lag between when a new census count is taken and when its results are applied to political reservations in the state legislature to identify the effect of minority political representation in the state legislature on policy outcomes. She finds that increasing minority representation increases transfers to minorities: ST reservation increased spending on ST welfare programs, and SC reservation increased the share of state government jobs set aside for minorities. Additionally, ST reservation lowered education spending and overall government spending. These results clearly establish that legislator identity matters for policy outcomes, but as Pande writes in her conclusion, "It would, however, be premature to view this paper's findings as suggesting that political reservation is a welfare-enhancing policy" (p. 1147). Our paper extends Pande's paper by examining poverty as an outcome;

\footnotetext{
${ }^{1}$ Dushkin (1972) and Parikh (1997) also provide useful background information on social groups and politics in India.
} 
we use the same identification strategy, also use state panel data, and also are concerned with minority political representation in the state legislature.

Several studies on the effects of political reservation examine a more local level of government, the Gram Panchayat (village council) level. Each Gram Panchayat is comprised of a small group of villages and is responsible for the administration of public goods in these villages. Some seats for pradhan (chief of the Gram Panchayat) are reserved for minorities and women, with the reserved seats randomly assigned across Gram Panchayats. This random assignment feature has been exploited by researchers to identify the effects of political reservation for women and minorities on the allocation of local public goods. Duflo and Chattopadhyay (2004) find that Gram Panchayats that are randomly assigned a female pradhan tend to spend more on public goods that women consider more important, such as drinking water and roads in West Bengal and drinking water in Rajasthan. Besley, Pande, Rahman and Rao (2004) find that having an SC/ST pradhan significantly increases the probability that SC/ST households have a toilet, electric connection or private water line provided by a government program since the last election. Bardhan, Mookherjee and Parra Torrado (2008) find that villages with an ST/SC pradhan tend to be allocated more benefits from the local government, such as more credit from the Integrated Rural Development Programme (IRDP). ${ }^{2}$ They do not find any increases in benefits among villages with a female pradhan, though. Finally, Duflo, Fischer and Chattopadhyay (2008) find that having an SC pradhan significantly increases public goods provided to hamlets where SC are concentrated.

The above studies convincingly show that political reservation affects policy outcomes and public goods provision in India, and seems to redistribute resources in favor of the targeted groups. But given the multifaceted effects, including increases in some types of resources but reductions in others, it is an empirical question whether political reservations provide net benefits to the populace. Our paper approaches this question by estimating the reduced-form

\footnotetext{
${ }^{2}$ Bardhan, Mookherjee and Parra Torrado (2005), using data on shorter run outcomes, also found a positive effect of having a minority pradhan on IRDP credit, but there were negative effects on spending on employment programs and agricultural wages.
} 
effect of political reservations for minorities on overall poverty. We do not purport to know or be able to estimate India's social welfare function. We note, though, that poverty reduction is a major objective of the Indian government, and therefore it is of interest to know, when all the changes in policy and resource allocation are taken together, whether political reservation for minorities reduced poverty. Does helping minorities through political reservations end up hurting the poor? If it does, then society must weigh the benefits to minorities against the harm to the poor. Otherwise, it can feel assured that helping minorities also helps alleviate poverty, which might soften some opponents of political reservation for minorities.

This is the first study to our knowledge that estimates the effect of any type of affirmation action policy on poverty. Additionally, it is one of only a few studies that estimates the net effect of affirmative action. ${ }^{3}$ Studies have tended to focus on the effect of affirmative action on intended beneficiaries, which we agree is the first step in the evaluation of affirmative action. There is good evidence in US and India that affirmative action does redistribute resources to the benefit of the targeted groups, so the next step is to figure out the net benefits (net of costs, including any costs to non-targeted groups).

\subsection{Political Reservation in State Legislative Assemblies for Sched- uled Castes and Scheduled Tribes in India}

Scheduled castes (groups having low social and ritual standing) and scheduled tribes (groups distinguished by their tribal culture and physical isolation) have historically been

\footnotetext{
${ }^{3}$ Bertrand, Hanna and Mullainathan (2008) estimate the effect of affirmation action in college admissions in India. They collect data on the labor market outcomes of applicants to an engineering college, and find that lower caste group applicants benefit from attending the college (which they would not have been able to attend without the reservations). However, the benefit is greater for the marginal high caste group applicant admitted compared to the marginal low caste group applicant admitted, which means that reserving college seats for lower caste group members leads to an inefficient allocation of educational slots. Chattopadhyay, Duflo and Fischer (2008) test for whether Gram Panchayats behave efficiently. They find that having an SC pradhan changes the composition of public goods provided, which indicates that the Gram Panchayat was not behaving efficiently under the assumption that preferences are homothetic. In this situation, reservation for minorities would raise efficiency-for a given level of resources allocated to minorities, the mix would now be allocated in greater accordance with their preferences.
} 
excluded from opportunities and rights that lead to socioeconomic advancement in Indian society. ${ }^{4}$ Combined with low social mobility-social group is hereditary, and marrying outside one's group is rare-the discrimination has led to poor socioeconomic outcomes for STs and SCs that are repeated generation after generation. In 2004-05, the share of the population living below the official Indian poverty line was $46 \%$ of STs and $37 \%$ of SCs; in contrast, it was $23 \%$ among non SC/STs. ${ }^{5}$ Thus the STs and SCs account for a disproportionate of India's poor: STs make up $8.6 \%$ of India's overall population but $14 \%$ of its poor, and SCs make up $20 \%$ of the population but $27 \%$ of the poor.

To improve the well-being of the SCs and STs, various affirmative action policies for SCs and STs have been instituted in the Indian Constitution. As far as political reservation is concerned, the original Indian Constitution (which took effect on January 26, 1950, creating the Republic of India) mandates representation for SCs and STs in the lower house of Parliament (the national legislative assembly) and the state legislative assemblies. Additionally, the 73rd and 74th Amendments of 1993 mandated representation for SCs and STs at a more local level of government. ${ }^{6}$ The seats for SCs and STs are set aside in proportion to their respective share of the total population in the state or part of state. Only members of the SC (ST) may stand for election in constituencies that have been reserved for SCs (STs), but voters of all social groups in the territorial constituency get to vote regardless of whether their constituency is reserved.

Since our empirical work concerns political reservation for SCs and STs in the state

\footnotetext{
${ }^{4}$ In the British era, these were called the depressed classes, and colloquially they have also been called the untouchables and backward classes though these terms are out of favor. The Constitution (Scheduled Castes) Order of 1950 and the Constitution (Scheduled Tribes) Order of 1950 lists which castes, races and tribes are designated SCs and STs, respectively. Pande (2003)'s Table 2 provides a concise summary of the criteria used to designate communities as SCs or STs.

${ }^{5}$ These figures are calculated based on data from the 61st round of the National Sample Survey, a nationally representative sample of households in India.

${ }^{6}$ The 73rd Amendment concerns local governing bodies in rural areas (including the Gram Panchayats), and 74th Amendment concerns local governing bodies in urban areas. In addition to the provisions for minority political representation, these amendments called for at least one-third of the seats in these local governing bodies to be reserved for women; prior to this, there was no political reservation for women in India. See Duflo (2005) for more on political reservation for women.
} 
legislature, we proceed by providing more detail about the role of the state legislature, how reservations in the state legislature are set and how they change. India is a federal union of states (like the United States). The state governments serve populations that are larger than many nations ${ }^{7}$ and have a good deal of autonomy from the central government. The Indian Constitution delineates the responsibilities of the state and central governments, with some items under the exclusive control of the central government, some under the exclusive control of the states and other items under joint jurisdiction. Among the items in the state governments' purview are public order, police, public health and sanitation, intrastate roads, water, land, agriculture and industries. Though items like education, social security and social insurance, and labor are under joint jurisdiction, in practice, state governments assume much of the responsibility. The primary way in which state legislative assemblies can affect outcomes in the state is through the allocation of state government spending. During the span of our data, 1960-1992, state governments undertook over half of total government expenditures in India [Khemani (2004), Rao and Singh (2001)]. Other ways include making laws, setting priorities, and managing lower levels of government. Thus the state assembly does have the meaningful power, and its composition can therefore have measurable consequences.

Political reservation for SCs and STs in the state legislative assemblies follows a single policy rule that applies to all states: according to Article 332 of the Indian Constitution, the number of seats reserved for SCs and STs is such that the share of total seats in the state assembly reserved for each group equals that group's share of the total state population in the last preceding census. This policy rule makes clear where variation in minority political representation comes from. The primary source is the arrival of new census population figures. In this case, the Delimitation Commission is responsible for delimiting the constituencies for the national and state legislatures based on the new population data, revising the number

\footnotetext{
${ }^{7}$ The 16 states in our sample range in population from 10 million (Jammu and Kashmir) to 166 million (Uttar Pradesh) according to the 2001 Census. These 16 states make up for over $95 \%$ of India's total population of one billion.
} 
of seats reserved in each state for SCs and STs based on the revised constituencies and each group's population share in the new census, and designating which specific constituencies are reserved for SCs and STs. ${ }^{8}$ In our data set, which spans 1960-1992, the arrival of the 1961 and 1971 census counts caused reservations to change in the late 1960s and late 1970s, respectively. To the end of our data period, representation continued to be based on the 1971 census since constitutional amendments postponed new delimitations of constituencies. ${ }^{9}$

Variation in share of seats reserved for SCs and STs also arises from institutional changes imposed from the national government. First, when the number of constituencies change, the share of seats reserved could change since the number of seats must be an integer. In 1961, two-seat constituencies were abolished, leading to fewer seats (previously, a given constituency could have multiple seats). Second, when the definition of ST or SC changes, the share of seats reserved change. The Scheduled Caste and Scheduled Tribe Orders Act of 1976, which mandated that a social group defined as a scheduled caste or scheduled tribe in any part of the state will be defined as so in the entire state, led to revised census figures for the SC and ST population and consequently revised reservations. ${ }^{10}$ Finally, when a state's borders changes, then its calculated minority population share will change, leading to changes in the share of seats reserved; this is variation that we do not use in our empirical work since we want states that are consistently defined over time. The Punjab Reorganization Act of 1966, in which the Punjab then in existence was divided into present-day Punjab and the new state of Haryana, is the instance during our 1960-1992 sample period in which some

\footnotetext{
${ }^{8}$ The Delimitation Commission is an ad hoc national committee formed after a census is taken, and is comprised of a supreme (national) court judge, high (state) court judge and the chief election commissioner. In each state, constituencies with the largest ST population are reserved for STs first. Which constituencies are reserved for SCs also depends on where SC population is higher, but with the constraint that the seats reserved for SCs be dispersed across the state.

${ }^{9}$ The 42nd Amendment in 1976 to the constitution postponed redistricting until after 2000, and the 84th Amendment in 2001 further postponed it to 2026. The intention behind freezing constituencies based on the 1971 census counts was to assure states that their representation in Parliament would not be perversely impacted by the successful implementation of family planning policies.

${ }^{10}$ It should be emphasized that the Constitution (Scheduled Castes) Order of 1950 and the Constitution (Scheduled Tribes) Order of 1950 make clear which groups are considered SCs and STs in each state. What the SC/ST Orders Act did was to make uniform the definition of SC/ST within a state.
} 
state borders changed. ${ }^{11}$

Table 1 summarizes the sources of variation in share of seats reserved for SCs and STs in state assemblies discussed above. It must be noted that reserved seats in state assemblies are not adjusted immediately after the arrival of a new census count or the institutional changes. Instead, they are applied to the next election, when the current (typically five-year) term of all the members of the state legislative assembly end and voters must elect all new members for the next term. Since state elections are not held at the same time across states, the same arrival of a new census count or institutional change causes the share of seats reserved to change in multiple years (the middle column of Table 1 shows the first year the revised reservations could have been implemented), changing sooner in states that happen to have a state election sooner. This difference in timing between when a new census count is taken and when reservations based upon it are implemented will be exploited for identifying the effects of reservation below.

\section{Empirical Strategy}

In theory, minority political reservation could increase or decrease poverty. Previous studies have found that political reservations for minorities tend to change policies and the allocation of public goods in favor of minorities. Such changes can be expected to improve the well-being of at least some minorities, and even non-minorities in poverty might benefit to the extent that these changes encapsulate more general anti-poverty measures than would otherwise have been undertaken. However, there might be elite capture (in which only the better off among the minorities receive the benefits) or the displacement of resources for nonminorities in poverty. In India, though the poverty rate is higher among minorities $(40 \%$ for SCs and STs compared to $23 \%$ for the rest of the population in 2004-05), the number of people in poverty is higher among non-minorities (12 million in poverty among SCs and STs

\footnotetext{
${ }^{11}$ A small part of Punjab was added to Himachal Pradesh, a union territory that became a state in 1971 and which is not part of our analysis.
} 
compared to 17 million in poverty in the rest of the population). In this context, helping minorities is not synonymous with reducing poverty-it could be that benefits are mostly go to the SCs and STs above the poverty line, or that the costs are borne predominantly by the non-minority poor. Thus, it is an empirical question whether minority political representation on net reduces poverty.

Suppose the relationship between minority share of legislative seats and poverty could be approximated as:

$$
y_{s t}=\alpha_{s}+\beta_{t}+\gamma \text { Minority } \operatorname{Rep}_{s t}+e_{s t}
$$

where $y_{s t}$ is the poverty rate in state s observed at time t. The variable Minority Rep $p_{s t}$ is the percentage of legislative seats held by minorities. $\alpha_{s}$ is the state fixed effects and control for any time-invariant state characteristics on poverty. $\beta_{t}$ is the time fixed effects and control for any macroeconomic shocks or national policies that affected all states uniformly. Finally, $e_{s t}$ is the state level error term. The coefficient of primary interest is $\gamma$, which estimates the effect of minority political representation on poverty. In general, estimating Equation 1 by ordinary least squares (OLS) would not provide the causal effect of minority political representation. This is because in general, there would be omitted variables bias-places that tend to elect more minorities likely differ in ways that affect poverty as well. For example, they might be less discriminatory, which affects both the election outcomes of minorities as well as their economic outcomes. Or, they might be more socially progressive, which causes more minority candidates to be elected as well as more anti-poverty policies. State (or place) fixed effects mitigate this concern somewhat; however, there might be time-varying state (or place) characteristics that matter, such as changing attitudes about minorities.

In the case of India, though, such omitted variables bias is averted because minority political representation in the state legislative assemblies is determined by a simple policy rule 
that applies to all states. ${ }^{12}$ This rule, that the share of the state's legislative assembly seats reserved for minorities must equal their share of the state's population, leaves no discretion on the part of individual states as far as minority political representation is concerned. As discussed in the previous section, all changes in reserved seats for minorities arise from the arrival of a new census count or institutional changes imposed from the central government. Thus, estimating Equation 1 using panel data on Indian states in the post-1950 era (after the Indian Constitution, which contained the rule, took effect) would lead to a less biased estimate of $\gamma$ than in the general case. However, an important concern remains: minority population share is positively correlated with minority political representation through the policy rule, but it might be correlated with poverty, too, for reasons other than minority political representation. This is quite plausible; for example, some resources may be allocated approximately on a headcount basis.

The obvious solution to address this concern-that minority population share is an omitted variable-is to add it as a control to Equation 1. If minority population share always exactly equalled share of seats reserved for minorities, though, there would be perfect collinearity and it would be impossible to separate out the effect of minority political representation. But in the case of India, three features of the policy rule and its implementation help us address the problem. First, the policy rule is based on minority population share in the last preceding census. Thus, we can control for minority population share of state $\mathrm{s}$ at time $\mathrm{t}$ in Equation 1 while still having variation left in the political reservation variable since the latter is based on a census (not an intercensal) population count. Second, the policy rule is implemented with a time lag. On the one hand, it takes several years for the Delimitation Commission to revise constituencies and reservations on the basis of the new census data. On the other hand, it could take several more years before a state implements the new

\footnotetext{
${ }^{12}$ Though SCs and STs can stand for election in unreserved constituencies, in fact virtually no seat has been won by SCs and STs in unreserved constituencies. Therefore, there is no difference between share of state legislative assembly seats held by SCs and STs and share of seats reserved for SCs and STs, and so the effect of minority political reservation that we estimate has the interpretation as the effect of minority political representation (in a context where there is affirmative action for minorities).
} 
reservations; states that have an election scheduled soon after the Delimitation Commission finishes would implement the new reservations earlier. Because of this time lag, we can control for minority population share in the last decennial census taken before time t while still having variation left in the political reservation variable. Third, the policy rule must be implemented subject to the constraint that the number of seats be an integer value. Thus due to rounding off to an integer, there will be instances in which the reserved share and the minority population share measured in the census do not match exactly.

Figure 1 illustrates the main features of our identification strategy. The most recent census count was taken in 1971. The Delimitation Act 1972 was passed on December 30, 1972 to form the Delimitation Commission and begin the process of revising constituencies and reservations based on the 1971 census. Once the revisions are complete (in 1974), they are implemented in each hypothetical state's next election. In Figure 1, the 1978 election is this state's first election following the revisions based on the 1971 census. Thus, between 1971 and 1977, although the 1971 census is available, the reserved seats continue to be based on the 1961 census. Additionally, since population is changing year to year, the current minority population share is in general different from either the census minority population share and the share of seats reserved. Thus, it is possible to control for minority population share in the current year as well as in the most recent census and still identify the effect of share of seats reserved for minorities.

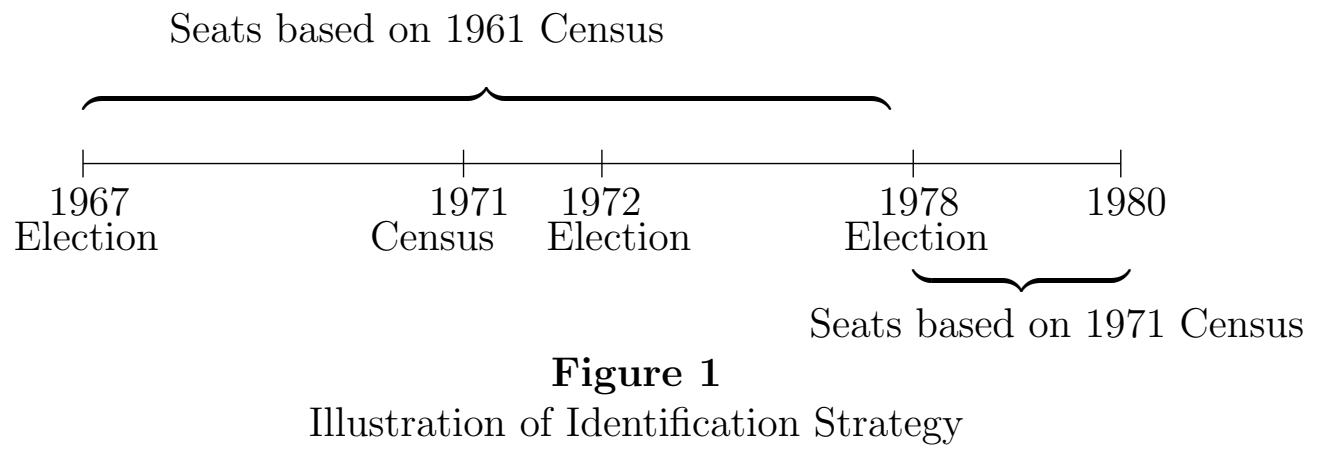

Modifying Equation 1 to address the problem of omitted minority population share, we 
get:

$$
y_{s t}=\alpha_{s}+\beta_{t}+\gamma \text { Minority Rep } \text { st }_{1}+\delta_{1} \text { Current Pop } p_{s t}+\delta_{2} \text { Census Pop } p_{s t}+\lambda X_{s t}+e_{s t}
$$

where Current Pop st is the minority share of the population in state $\mathrm{s}$ at time $\mathrm{t}$ and Census Pop st is the minority share of the population in state $\mathrm{s}$ at the time of the last preceding census. ${ }^{13}$ In some of our estimated regression models below, we will also control for some additional variables, $X_{s t}$ (specifically, state income last year, dummy for election year, population density in last preceding census, rural share of population and total population).

\section{Data}

We implement our empirical strategy using state panel data on the sixteen major Indian states from the period 1960-1992. ${ }^{14}$ These are the states that existed in India following the States Reorganization Act of 1956, which divided India into linguistic-based states. ${ }^{15}$ These states contain $95 \%$ of the Indian population during the period of study. ${ }^{16}$ The state is an appropriate unit of analysis for the research question at hand-the state legislature is making decisions about resource allocation and policies, and we are asking whether minority representation in the legislature affects poverty through these decisions. ${ }^{17}$ Additionally, it is

\footnotetext{
${ }^{13}$ For the census years in our sample, i.e., $\mathrm{t}=1961,1971,1981$ and 1991, the Current Pop st $_{\text {is }}$ identical to Census Popst.

${ }^{14}$ These states are Andhra Pradesh, Assam, Bihar, Gujarat, Haryana, Jammu and Kashmir, Karnataka, Kerala, Madhya Pradesh, Maharashtra, Orissa, Punjab, Rajasthan, Tamil Nadu, Uttar Pradesh and West Bengal.

${ }^{15}$ There were thirteen states defined under this act, but in 1960 the state of Bombay was divided into Gujarat and Maharashtra, and in 1966 Punjab was divided into Haryana and Punjab.

${ }^{16}$ Excluded from our analysis are the union territories defined in the States Reorganization Act of 1956, which do not have the same degree of autonomy from the central government as the states. Some of these union territories have since attained statehood.

${ }^{17}$ Even with microdata, the policy variable remains at the state-time level. However, microdata would permit greater exploration of heterogeneity of effects, which could be a worthwhile future exercise.
} 
appropriate to end the data series at 1992. The 73rd and 74th constitutional amendments of 1993 extended political reservation for minorities to local governing bodies, so outcomes in 1993 and later are the result of a different institutional arrangement in which more power devolved from the state governments to the local governments. ${ }^{18}$ For continuity in the definition of state and state government in the sample, we therefore use the 1960-1992 time period. ${ }^{19}$

The variables used in our empirical analysis are gathered from various Indian government sources. We describe these variables below. Basically, our data set is the same as the one used in Pande (2003) with the addition of poverty data from the Ozler, Datt and Ravallion (1996) and political data from the Election Commission of India. ${ }^{20}$

Poverty outcomes: We use three measures of poverty: (1) headcount ratio, which is the proportion of the population below the poverty line, (2) poverty-gap index, which is headcount ratio multiplied by the mean percentage shortfall of consumption from the poverty line among the poor, and (3) squared poverty-gap index, which is a variant of the poverty-gap index that gives even more weight to very poor. ${ }^{21}$ Whereas headcount ratio measures the incidence of poverty, poverty-gap index and squared poverty-gap index capture the intensity of poverty by giving individuals farther below the poverty line more weight. We obtained these poverty measures from Ozler, Datt and Ravallion (1996). They constructed

\footnotetext{
${ }^{18}$ Reservation for minorities in the local governing bodies is also based on minority population shares in the last census, making it difficult to separately identify effects of reservation in the state assemblies versus the local governing bodies.

${ }^{19}$ With 16 states and 33 years, there are 528 potential state-year cells. We lose 21 cells due to the following. First, Haryana and Punjab enter the data set in 1967; before 1967, Haryana was part of Punjab so Punjab pre-1967 had different borders and population than post-1967. Second, Gujarat and Maharashtra enter the data set in 1962; though formed in 1960, data on elections (and so, reserved seats) is first available in 1962. Finally, for Jammu and Kashmir, 1962 is the first year when data on elections (and so, reserved seats) is available, and poverty data is not available in 1992.

${ }^{20}$ We are grateful to Pande for providing us her data.

${ }^{21}$ These three measures belong to the Foster, Greer and Thorbecke (1984) class of poverty measures. For the squared poverty-gap index, each individual's poverty-gap index is being weighted by the individual's shortfall of expenditure from the poverty line. As Deaton and Dreze (2002) note, this measure, unlike poverty-gap index, is sensitive to the distribution of income below the poverty line, which is a desirable feature for a poverty measure. However, it is more sensitive to measurement error at the bottom of the income distribution.
} 
a consistently defined series on headcount ratio, poverty-gap index and squared povertygap index using household-level consumption expenditure data from twenty rounds of the National Sample Survey (NSS) spanning the period 1960-1992. ${ }^{22}$ They use the same poverty line used by the Government of India-the nutritional norm of 2400 calories per capita per day for rural areas and 2100 calories per capita per day in urban areas. ${ }^{23}$ Individuals in households where the per capita expenditure level is insufficient to meet the calorie norms are classified as in poverty. ${ }^{24}$ The headcount ratio, poverty-gap index, and squared povertygap index are measured separately for rural and urban areas of each state; more than $70 \%$ of the Indian population lives in rural areas.

There are alternative ways to measure poverty, but we argue that for our analysis, the headcount ratio, poverty-gap index and squared poverty-gap index from Ozler et al. are especially relevant. They are calculated in the same way as that used by the Government of India. Thus, these are the figures used for planning purposes and reported by the media in India. To the extent that politicians are held accountable for poverty outcomes, it would be these measures of poverty that would be available and used. Besley and Burgess (2000) also used the poverty measures from Ozler et al. in their study of the effect of states' land reform policies on poverty in India. As well, Burgess and Pande (2005) used them in their study of the effect of increasing access to banking on poverty in India.

Minority political reservation: We measure minority political reservation as follows: (1) percentage of seats in state assembly reserved for SC ("SC Share Reserved"); and (2) percentage of seats in state assembly reserved for ST ("ST Share Reserved"). We obtained information on the share of seats reserved for SCs and STs from the Election Commission of India reports on state elections. The Election Commission is an independent agency set up in

\footnotetext{
${ }^{22}$ NSS surveys were conducted in the years $1961,1962,1963,1965,1966,1967,1968,1969,1970,1971,1973$, 1974, 1978, 1983, 1987, 1988, 1990, 1991, 1992, 1993, 1994, 1995, 1996, 1997, 2000. Weighted interpolation has been used to obtain the poverty estimates for years when no NSS survey was conducted. Our results remain when we restrict analysis to those years with NSS surveys.

${ }^{23}$ These norms were set by the Planning Commission (1993).

${ }^{24}$ The expenditure level to meet the calorie norms varies by sector (urban/rural), state and year. See Datt (1995) for the details in constructing the poverty measures in Ozler et al.
} 
the Indian Constitution to conduct elections, and is the authoritative source on data related to elections. These reports contain constituency-level data for each state election, including information about which seats are reserved for SCs and STs. We obtained useful institutional details about minority political reservation from the Scheduled Caste and Scheduled Tribe Commissioner's annual reports and conversations with officials in that office.

Minority population share controls: To estimate Equation 2, we require data on the SC and ST share of the population according to the last preceding census and to current population estimates. Censuses of the population are taken decennially, and we use data from the following censuses: 1951, 1961, 1971, 1981 and 1991 (Census of India, Registrar General). Intercensal estimates of the population are obtained via linear interpolation, as in Pande (2003).

Other controls: In some specifications, we will control for state income last year, dummy for election year, population density in last preceding census, rural share of population and total population. First, the state income measure we use is the log of real per capita state domestic product. The data source is the Planning Commission, Government of India. Second, a dummy variable for election year takes on the value one when there is a state election in year t. This information comes from the Election Commission's reports on state elections. Third, total population count comes from the Census of India, Registrar General, with intercensal estimates interpolated. Fourth, population density is computed as the total population in the state according to the last preceding census divided by total land area of the state. Finally, rural population share comes from Ozler et al. and is computed from the National Sample Survey.

The means and standard deviations of the variables used in our estimation below are reported in Table 2 . 


\section{$5 \quad$ Estimation Results}

\subsection{Main Results}

We first estimate the effect of minority political reservation on the headcount ratio, i.e., the percentage of the population living below the poverty line. These results are presented in Table 3. Each column reports the results from a separate regression estimated using ordinary least squares. The dependent variable is rural headcount ratio in Columns 1-3, urban headcount ratio in Columns 4-6 and aggregate (rural and urban combined) poverty in Columns 7-9. Standard errors are clustered by state. ${ }^{25}$

Column 1 shows the results from estimating Equation 1, where Equation 1 has been modified to allow for reservations for two disadvantaged minority groups: Scheduled Castes ("SC Share Reserved") and Scheduled Tribes ("ST Share Reserved"). The coefficient for SC Share Reserved is -0.421 and statistically insignificant, and the coefficient for ST Share Reserved is -1.297 and significant at the $95 \%$ level of confidence. As discussed in Section 3, estimates using Equation 1 may be biased due to omitted variables bias-minority population share is positively correlated with share of seats reserved due to the policy rule, and could be correlated with poverty as well. In Columns 2-3, we therefore estimate Equation 2 (modified to allow for two minority groups), which controls for population share of SCs and STs in the last preceding census as well as the current year. Equation 2 is our preferred specification, exploiting only the variation in minority political reservation that arises from national policies that cause reservations to be revised and the time lags with which the revised reservations are implemented due to the timing of state elections. In Column 2, the effect of share of seats reserved for SCs remains insignificant and the effect of share of seats reserved for STs remains negative and statistically significant after controlling for census and current population shares of SCs and STs in the state. In Column 3, we add a few variables that might

\footnotetext{
${ }^{25}$ Though the policy variables are at the state-time level, it is desirable to cluster by state because serial correlation may be present [Bertrand, Duflo and Mullainathan (2004)].
} 
be correlated with both the reservation variable and the outcome: state income last year, election year dummy, total population, population density and rural share of population. The same findings hold. First, SC political reservation has no impact on the incidence of poverty in rural areas. Second, a one percentage point increase in seats reserved for STs in the state assembly would lead to a 1.4 percentage point decrease in the rural poverty rate in the state.

Columns 4-6 show the parallel results with urban headcount ratio as the dependent variable. In Columns 5 and 6, which control for census and current population shares of SCs and STs, we find negative point estimates, but they are not significant with $95 \%$ confidence. Thus, there is only weak evidence of a reduction in the incidence of poverty in urban areas due to minority political reservations.

Not surprisingly given our findings for rural and urban headcount ratio, in Columns 7-9 we find that SC reservation does not affect aggregate poverty but ST reservation reduces it. In particular, a one percentage point increase in seats reserved for STs would lead to a 1.2 percentage point decrease in the aggregate poverty rate in the state.

Besides the impact of minority political reservation on the incidence of poverty, the impact on the intensity of poverty is also of interest. In Table 4, we show the effects on poverty-gap index (Columns 1-4) and squared poverty-gap index (Columns 5-8). In both rural and urban areas, ST reservation reduces the depth of poverty (measured by the poverty-gap index) and the severity of poverty (measured by squared poverty-gap index). This is suggestive that ST reservation did not only bring people just below the poverty line across it. It also appears to have helped those further below the poverty line.

To summarize, the main result of this paper is that minority political reservation reduced poverty in India. Specifically, we find that reserving more seats for STs significantly reduces the incidence and intensity of poverty in rural and urban areas. We do not find a significant effect of SC reservation on any of our poverty measures, though we cannot rule out a modest negative effect on the urban poverty rate. Though the estimates are somewhat imprecise, 
generally we find that the effects of ST reservation is statistically significantly different from the effects of SC reservation. ${ }^{26}$

The two observations-(1) that ST reservation reduces poverty while SC reservation does not, and (2) that the negative effect of ST reservation poverty is greater in rural areas than urban areas-might be explained by the following differences between the SC and ST communities. First, STs are more likely to live in rural areas (91\% rural for STs compared to $80 \%$ for SCs according to $2004-05$ NSS) and more likely to be in poverty (46\% for STs and $40 \%$ for SCs). Moreover, STs are more likely to live in local communities in which they are a majority. ${ }^{27} \mathrm{SCs}$, though, are fairly evenly distributed throughout the state, and rarely comprise a majority in their local communities. Finally, within a local community, members of STs tend to be from the same specific scheduled tribe whereas there is more within-group heterogeneity among members of SCs (even in a given locality, there are numerous castes and subcastes within SCs). The geographic concentration of STs may facilitate the targeting of resources toward them (i.e., provide resources to STs without much slippage to other social groups). The greater homogeneity within the local community among members of STs may improve the efficacy of these resources (e.g., more cooperative outcome, better delivery) (Alesina, Baqir and Easterly, 1999; Miguel and Gugerty, 2005). Thus, when resources are reallocated in favor of STs, they will tend to go to rural areas, be more likely to reach the STs within those rural areas, and possibly be used more effectively. For resources allocated in favor of SCs on the other hand, there may be more contention over where these resources should go due to geographic dispersion and greater heterogeneity. Since it is the better off among the SCs who tend to win the seats reserved for SCs (Dushkin, 1972), more resources allocated in favor of SCs may end up going to the better off among the SCs (e.g. positions as heads of ministries, government jobs, scholarships), so poverty decreases by less (if at all)

\footnotetext{
${ }^{26}$ In Tables 3 and 4, the last line displays the results of F-tests of the equality of the effects of ST and SC political reservation.

${ }^{27}$ Though STs account for about $8 \%$ of the overall population, they often account for a majority of the population in their local communities.
} 
due to SC reservation.

Perhaps the real surprise is that ST reservation should reduce poverty incidence and intensity in urban areas at all, given that less than $10 \%$ of the ST population live there and these urban STs are not as badly off as the rural STs. However, even in the cities the STs tend to live in pockets together. Moreover, it could be that the urban poor-both from minority and non-minority groups-are benefiting from the general poverty reduction policies that ST state legislators tend to push. It is likely that the poor in non-ST social groups experience some benefits because otherwise the effect on ST poverty in urban areas seems quite large. $^{28}$

These two observations are consistent with Pande (2003). She found that ST political reservations in the state assembly significantly raised spending on ST welfare programs while SC political reservations are associated with more state government jobs reserved for minorities; ST reservation did not affect hob reservations and SC reservations did not affect spending on SC welfare programs. More spending on ST welfare programs would tend to reduce poverty more, especially in rural areas (since over $90 \%$ of STs live in rural areas). On the other hand, more public sector jobs for minorities would tend to help the better off more (though there are some unskilled government jobs, most require skills that the poor are less likely to possess), so there will be less impact on the poverty margin. Of course there are numerous mechanisms through which representation in the state assembly could affect poverty, and the policies analyzed by Pande are only a subset, but even looking at this subset we can see why ST reservation would reduce poverty, especially rural poverty, while $\mathrm{SC}$ reservation might not have a measured effect on poverty.

\footnotetext{
${ }^{28}$ For example, in 2004-05, a year for which we have group-specific poverty data, though one-third of urban STs are poor, urban STs account for less than $4 \%$ of the urban poor. The point estimates in Table 3 suggest that a one percentage point increase in reserved seats for STs leads to a 0.4 percentage point reduction in the urban poverty rate. If this effect came entirely from reductions in ST urban poverty, then $10 \%$ of the ST urban poor would be exiting poverty. Alternatively, ST urban poverty decreases by less with poverty for other groups declining also.
} 


\subsection{Robustness Checks}

We have been interpreting the estimated coefficient for the minority political reservation variable in Equation 2 as the causal effect of minority political reservation. The foundation for this causal interpretation is that we are only using variation in seats reserved arising from the time lag between when a new census count is available and when revised reservations based on the new census count are implemented. In this subsection, we consider several hypotheses that would confound a causal interpretation.

Control for nonlinear effects of minority population share: Our identification strategy is a regression-discontinuity-type approach in the sense that share of seats reserved in the state assembly is a discontinuous function of their population share in the state. Thus it is essential to control adequately for minority population share so that identification is solely from the discontinuities. In our preferred specification (Equation 2), we controlled linearly for minority population share in the last census as well as in the current year. This leaves open the possibility that we are incorrectly attributing some nonlinear effects of minority population share to minority political reservation. We address this concern in the following three robustness checks. To preview these results, we find our results remain even when we control for more complex functional forms for minority population share.

First, we augment Equation 2 with quadratic controls for SC and ST population share in the last preceding census. The estimated effects of ST Share Reserved and SC Share Reserved for this specification are shown in Table 5, Column 2 (Column 1 reports the results of the original specification, which were previously shown in Table 3, Columns 3,6 and 9, to facilitate comparison). The effects are the same as before: there is no effect of SC Share Reserved on any of the poverty measures, and ST Share Reserved has a negative effect that is significant at the $5 \%$ level for rural and aggregate poverty, and that is weakly significant for urban poverty.

Second, we add to Equation 2 one and two-year lagged values of current population share 
of SC and ST for each state. These estimated effects, shown in Column 3, are essentially unchanged from the baseline effects in Column 1.

Finally, we restrict our sample to a narrower window around the discontinuous points, i.e., election years in which revised reservations are first implemented. Specifically, we only use observations two years before, during and after such an election year in the state. The results are displayed in Column 4, and are similar to the original results. Due to the reduction in number of observations (288 instead of 496), though, the standard errors are somewhat larger and these estimates are significant only at the $10 \%$ significance level.

Restrict to years with NSS data: Our poverty measures come from Ozler et al. (1996), which constructed them using twenty rounds of NSS data. The poverty measures are interpolated for years when NSS data are not available. This will tend to cause measurement error in the dependent variable. If this were classical measurement error, then our estimates would be consistent though less precise. However, it is possible that there is nonclassical measurement error such that the estimates might not even be consistent. To address this concern, we drop the years for which the poverty estimates were interpolated: 1964, 1975, 1976, 1977, 1979, 1980, 1981, 1982, 1984, 1985, 1986, and 1989. The results using this smaller sample are shown in Column 5. The estimated effects are similar to the original ones.

\section{Discussion}

This paper is the first to quantify the effect of an affirmative action policy on poverty, and among the few to estimate an overall effect of an affirmation action policy (i.e., not only the effect on the intended beneficiaries). We used a natural experiment in India to identify the effect of political reservations for disadvantaged minority groups on overall poverty. The Indian Constitution stipulates that the number of seats reserved for Scheduled Castes and Scheduled Tribes in the state legislative assemblies must be in proportion to each group's share of the state population as enumerated in the most recent census. There is a time 
lag, though, between when reservations are revised (say, due to the arrival of a new census count) and when the revised reservations get implemented due to the staggered timing of state elections. This permits the identification of the effect of minority political reservation while controlling for minority population share since the former is a discontinuous function of the latter. Applying this empirical strategy to panel data on Indian states for 1960-92, we find that SC political reservation had no impact on poverty while ST political reservation reduced both the incidence and intensity of poverty. Increasing the share of seats reserved for STs by one percentage point reduced poverty in India by 1.2 percentage points. ST political reservation appears to have been more effective at reducing poverty in rural areas than urban areas.

This paper provides evidence that, contrary to widespread belief, the benefits from affirmative action are not always captured by the better off. Indeed, in the case of political reservation for STs in India, the poor-including those far below the poverty line-have benefited too. Thus, minority political reservation is a policy that is both pro-minority and pro-poor.

Given the net reduction in poverty, likely there was redistribution from richer to poorer. ${ }^{29}$ But governments routinely engage in income redistribution, which is perceived as far less controversial than redistribution from one ethnic group to another. Assuming that nonminorities gain no more than minorities, the political reservation policy generated more gains to minorities than losses to non-minorities. It is even possible that both minorities and non-minorities gain (e.g., because ST legislators strongly promote anti-poverty programs). So though we cannot rule out that there is redistribution from non-minorities to minorities, we can say that it does not appear to be the non-minorities near the poverty line who are

\footnotetext{
${ }^{29}$ Minority political reservation might generate efficiency gains which could help reduce poverty even without income redistribution. Duflo, Fischer and Chattopadhyay (2008) suggested one way minority political representation could increase efficiency-it increases information about preferences of minorities, leading to a more optimal allocation of resources earmarked for minorities. There are other mechanisms. For example, it could end a nutrition-based (or more generally, a human-capital-based) poverty trap. This means that providing extra consumption to people below poverty has higher returns than providing the same extra consumption to richer people.
} 
bearing the expense for the minorities' gains (for if they were, overall poverty would not have declined). Moreover, given that there are net gains for the policy, it should be possible to offer compensation to any non-minorities near the poverty line who are made worse off.

The empirical evidence in this paper suggests that the effects of affirmation action policies estimated in one context may be hard to generalize to other contexts. We found that while political reservations for one social group, the STs, did help reduce poverty, political reservations for another similarly impoverished group, the SCs, did not. ${ }^{30}$ This mirrors a finding from Prakash (2008), who estimates the effects of reserving government jobs for disadvantaged minorities on their employment outcomes in India-SC job reservations help the SCs, but ST job reservations do not appear to help the STs. This is also consistent with Pande (2003), who finds that SC political reservation changed policies in different ways than ST political reservation. The preferences of SCs and STs differ, and some of the constraints that they face differ too, and these differences have implications for the effects of affirmative action policies. Given this, it seems useful to state clearly what are the objectives of affirmative action so that the appropriate policies can be designed to meet these objectives; broad stroke affirmative action policies are unlikely accomplish them for all groups.

\footnotetext{
${ }^{30} \mathrm{SC}$ political reservation may nonetheless be beneficial to SCs and other social groups, but just not in terms of reducing poverty.
} 


\section{References}

Bardhan, Pranab; Mookherjee, Dilip and Parra Torrado, Monica L. "Impact of Reservations of Panchayat Pradhans on Targeting in West Bengal." Boston University Working Paper, November 2005.

Bardhan, Pranab; Mookherjee, Dilip and Parra Torrado, Monica L. "Impact of Political Reservations in West Bengal Local Governments on Public Service Provision.” Boston University Working Paper, July 2008.

Bertrand, Marianne; Duflo, Esther and Sendhil Mullainathan. "How Much Should We Trust Differences-In-Differences Estimates?" Quarterly Journal of Economics, February 2004, 119 (1), pp 249-275.

Bertrand, Marianne; Hanna, Rema and Sendhil Mullainathan. "Affirmative Action in Education: Evidence From Engineering College Admissions in India." NBER Working Paper 13926, April 2008.

Besley, Timothy and Burgess, Robin. "Land Reform, Poverty Reduction, and Growth: Evidence from India." Quarterly Journal of Economics, May 2000, 115 (2), pp. 389-430.

Besley, Timothy; Pande, Rohini; Rahman, Lupin and Rao, Vijayendra. "The Politics of Public Good Provision: Evidence from Indian Local Governments." Journal of the European Economic Association Papers and Proceedings, April-May 2004, 2 (2-3), pp. 416-426.

Burgess, Robin and Pande, Rohini. "Do Rural Banks Matter? Evidence from the Indian Social Banking Experiment." American Economic Review, June 2005, 95 (3), pp. 780795.

Chattopadhyay, Raghabendra and Duflo, Esther. "Women as Policy Makers: Evidence from a Randomized Policy Experiment in India." Econometrica, September 2004, 72 (5), 
pp. $1409-1443$.

Chen, Shaohua and Ravallion, Martin. "The Developing World is Poorer Than We Thought, But No Less Successful in the Fight Against Poverty." Policy Research Working Paper 4703, World Bank Development Research Group, August 2008.

Datt, Gaurav. "Poverty in India 1951-92: Trends and Decompositions." Policy Research Department, World Bank, 1995.

Deaton, Angus and Dreze, Jean. "Poverty and Inequality in India A Re-Examination." Economic and Political Weekly, September 7, 2002, pp. 3729-3748.

Duflo, Esther. "Why Political Reservations?" Journal of the European Economic Association, April-May 2005, 3 (2-3), pp. 668-678.

Duflo, Esther; Fischer, Greg and Chattopadhyay, Raghabendra. "Efficiency and Rent Seeking in Local Government: Evidence from a Randomized Policy Experiments in India." MIT Working Paper, July 2008.

Dushkin, Lelah. "Scheduled Caste Politics," in J. Michael Mahar, eds., The Untouchables in Contemporary India. Arizona: The University of Arizona Press, 1972, pp. 917-961.

Election Commission of India. Statistical Reports on State Elections in India, 1951-2000, New Delhi.

Foster, James; Greer, Joel and Thorbecke, Eric. "A Class of Decomposable Poverty Measure." Econometrica, May 1984, $52(3)$, pp. 761-766.

Galanter, Marc. Competing Equalities: Law and the Backward Classes in India. Berkeley: University of California Press, 1984.

Holzer, Harry J. and Neumark, David. "Assessing Affirmative Action." Journal of Economic Literature, September 2000, 38 (3), pp.483-568. 
Khemani, Stuti. "Political Cycles in a Developing Economy: Effect of Elections in the Indian States." Journal of Development Economics, February 2004, 73 (1), pp. 125-154.

Miguel, Edward and Mary Kay Gugerty. "Ethnic Diversity, Social Sanctions, and Public Goods in Kenya." Journal of Public Economics, 2005, 89, pp. 2325-2368.

Ozler, Berk; Datt, Gaurav and Ravallion, Martin. A Database on Poverty and Growth in India, World Bank Development Research Group, Washington DC, 1996.

Pande, Rohini. "Can Mandated Political Representation Increase Policy Influence for Disadvantaged Minorities? Theory and Evidence from India." American Economic Review, September 2003, 93 (4), pp. 1132-1151.

Parikh, Sunita. Politics of Preference: Democratic Institutions and Affirmative Action in the United States and India. Michigan: University of Michigan Press, 1997.

Planning Commission of India. Report of The Expert Group on Estimation of Proportion and Number of Poor. Planning Commission, Government of India, New Delhi, July 1993.

Prakash, Nishith. "Improving the Labor Market Outcomes of Minorities: The Role of Employment Quota." University of Houston Mimeo, 2008.

Rao, Govind M. and Singh, Nirvikar. "The Political Economy of Center-State Fiscal Transfers in India." Center for Reserach on Economic Develoipment and Policy Reform, Working Paper No. 107, September 2001. 


\section{TABLE 1}

Legislation Affecting Share of State Legislative Assembly Seats Reserved for SCs and STs during 1960-92

\begin{tabular}{|c|c|c|}
\hline Name of Legislation & $\begin{array}{l}\text { Year First } \\
\text { Implemented }\end{array}$ & Explanation \\
\hline $\begin{array}{l}\text { Two-Member Constituencies } \\
\text { Abolition Act } 1961\end{array}$ & 1962 & $\begin{array}{l}\text { Two-member territorial } \\
\text { constituencies abolished }\end{array}$ \\
\hline Punjab Reorganization Act 1966 & 1967 & $\begin{array}{l}\text { Reorganization of Haryana } \\
\text { and Punjab }\end{array}$ \\
\hline Delimitation Commission Act 1962 & 1967 & Revised in line with 1961 census count \\
\hline Delimitation Act 1972 & 1974 & Revised in line with 1971 census count \\
\hline $\begin{array}{l}\text { Scheduled Caste and Scheduled Tribe } \\
\text { Orders Act of } 1976\end{array}$ & 1977 & $\begin{array}{l}\text { Definitions of SCs and STs } \\
\text { made uniform within a state, } \\
\text { leading to official revisions of } 1971 \text { census } \\
\text { SC and ST population counts }\end{array}$ \\
\hline
\end{tabular}


TABLE 2

Descriptive Statistics

\begin{tabular}{lll}
\hline \hline & & $\begin{array}{l}\text { Standard } \\
\text { Deviation }\end{array}$ \\
Variable & Mean & \\
\hline Poverty Outcomes: & 49.04 & $(13.13)$ \\
Headcount ratio (Aggregate) & 50.76 & $(14.11)$ \\
Headcount ratio (Rural) & 43.05 & $(12.85)$ \\
Headcount ratio (Urban) & 14.89 & $(6.22)$ \\
Poverty-gap index (Rural) & 12.50 & $(5.59)$ \\
Poverty-gap index (Urban) & 6.01 & $(3.18)$ \\
Squared poverty-gap index (Rural) & 4.98 & $(2.83)$ \\
Squared poverty-gap index (Urban) & & \\
& & \\
Minority Political Reservation: & 14.01 & $(5.46)$ \\
SC share reserved & 7.38 & $(7.79)$ \\
ST share reserved & & \\
& & \\
Minority Population Share Controls: & 14.01 & $(5.55)$ \\
SC census population share & 7.47 & $(7.55)$ \\
ST census population share & 14.31 & $(5.51)$ \\
SC current population share & 7.42 & $(7.49)$ \\
ST current population share & & \\
& & \\
Other Controls: & & \\
Log of state income per capita last year & 6.88 & $(0.31)$ \\
Election dummy & 0.23 & $(0.42)$ \\
Population density & 237.20 & $(155.68)$ \\
Total population & $3.90 \mathrm{e}+07$ & $(2.51 \mathrm{e}+07)$ \\
Rural population share & 0.78 & $(0.07)$ \\
\hline \hline
\end{tabular}

Notes: State-year data for the 16 major Indian states from 1960-92 as described in Section 4. There are 507 observations for all variables except state income last year, which has 496 observations because the state income data series does not begin until 1960. 
TABLE 3

Effect of Minority Political Representation on Incidence of Poverty

\begin{tabular}{|c|c|c|c|c|c|c|c|c|c|}
\hline & \multicolumn{9}{|c|}{ Headcount Ratio } \\
\hline & \multicolumn{3}{|c|}{ Rural } & \multicolumn{3}{|c|}{ Urban } & \multicolumn{2}{|c|}{ Aggregate } & \multirow[b]{2}{*}{$(9)$} \\
\hline & (1) & $(2)$ & $(3)$ & $(4)$ & $(5)$ & (6) & (7) & $(8)$ & \\
\hline \multirow[t]{2}{*}{ SC Share Reserved } & -0.421 & -0.339 & 0.077 & $-0.262^{*}$ & $-0.297^{*}$ & -0.121 & -0.365 & -0.318 & 0.063 \\
\hline & $(0.489)$ & $(0.498)$ & $(0.284)$ & $(0.150)$ & $(0.105)$ & $(0.206)$ & $(0.408)$ & $(0.416)$ & $(0.217)$ \\
\hline \multirow[t]{2}{*}{ ST Share Reserved } & $-1.297^{* * *}$ & $-1.432^{* * *}$ & $-1.388^{* *}$ & $-0.634^{*}$ & $-0.459^{*}$ & -0.434 & $-1.120^{* * *}$ & $-1.194^{* *}$ & $-1.191^{* *}$ \\
\hline & $(0.399)$ & $(0.450)$ & $(0.534)$ & $(0.228)$ & $(0.233)$ & $(0.268)$ & $(0.347)$ & $(0.410)$ & $(0.486)$ \\
\hline \multirow[t]{2}{*}{ SC Census Pop Share } & & -0.013 & 0.037 & & $-0.230^{* * *}$ & $-0.170^{* *}$ & & -0.054 & 0.004 \\
\hline & & $(0.102)$ & $(0.096)$ & & $(0.067)$ & $(0.068)$ & & $(0.088)$ & $(0.079)$ \\
\hline \multirow[t]{2}{*}{ ST Census Pop Share } & & 0.475 & 0.132 & & -0.424 & -0.519 & & 0.376 & 0.089 \\
\hline & & $(0.666)$ & $(0.756)$ & & $(0.466)$ & $(0.455)$ & & $(0.554)$ & $(0.604)$ \\
\hline \multirow[t]{2}{*}{ SC Current Pop Share } & & $-1.257^{* *}$ & -0.527 & & $1.429^{* * *}$ & $1.699^{* * *}$ & & -0.650 & -0.072 \\
\hline & & $(0.476)$ & $(0.712)$ & & $(0.414)$ & $(0.549)$ & & $(0.451)$ & $(0.617)$ \\
\hline \multirow[t]{2}{*}{ ST Current Pop Share } & & -0.096 & -0.289 & & -0.007 & -0.270 & & -0.196 & -0.372 \\
\hline & & $(0.785)$ & $(0.699)$ & & $(0.689)$ & $(0.509)$ & & $(0.685)$ & $(0.591)$ \\
\hline \multirow[t]{2}{*}{ State Income Last Year } & & & $-13.689^{* * *}$ & & & -0.775 & & & $-11.136^{* *}$ \\
\hline & & & $(4.654)$ & & & $(3.225)$ & & & $(4.331)$ \\
\hline \multirow[t]{2}{*}{ Population Density } & & & $-0.070^{* *}$ & & & -0.033 & & & $-0.062^{* *}$ \\
\hline & & & $(0.029)$ & & & $(0.021)$ & & & $(0.026)$ \\
\hline \multirow[t]{2}{*}{ Election Year Dummy } & & & 0.539 & & & 0.561 & & & 0.525 \\
\hline & & & $(0.600)$ & & & $(0.395)$ & & & $(0.443)$ \\
\hline \multirow[t]{2}{*}{ Rural Population Share } & & & 68.713 & & & 0.339 & & & $68.593^{*}$ \\
\hline & & & $(44.635)$ & & & $(54.426)$ & & & $(38.911)$ \\
\hline \multirow[t]{2}{*}{ Total Population } & & & $1.60 e-07$ & & & $2.52 e-07^{*}$ & & & $1.94 e-07^{*}$ \\
\hline & & & $(1.10 \mathrm{e}-07)$ & & & $(1.23 \mathrm{e}-07)$ & & & $(1.01 \mathrm{e}-07)$ \\
\hline State and Year Fixed Effects & YES & YES & YES & YES & YES & YES & YES & YES & YES \\
\hline No of Observations & 507 & 507 & 496 & 507 & 507 & 496 & 507 & 507 & 496 \\
\hline Adjusted $R^{2}$ & 0.84 & 0.85 & 0.87 & 0.90 & 0.91 & 0.92 & 0.87 & 0.87 & 0.89 \\
\hline \multicolumn{10}{|c|}{ p-value of F-test of equality of effects of SC and ST shares reserved } \\
\hline & {$[0.206]$} & {$[0.071]$} & {$[0.031]$} & {$[0.174]$} & {$[0.513]$} & {$[0.363]$} & {$[0.210]$} & {$[0.113]$} & [0.041] \\
\hline
\end{tabular}

Notes: Standard errors clustered by state are in parentheses. "SC(ST) Census Pop Share" is the SC (ST) share of the state population according to the last preceding census. "SC(ST) Current Pop Share" is the SC (ST) share of the state population measured in the current year.

Asterisks denote significance levels $\left(*=.10,{ }^{* *}=.05,{ }^{* * *}=.01\right)$ 
TABLE 4

Effect of Minority Political Representation on Intensity of Poverty

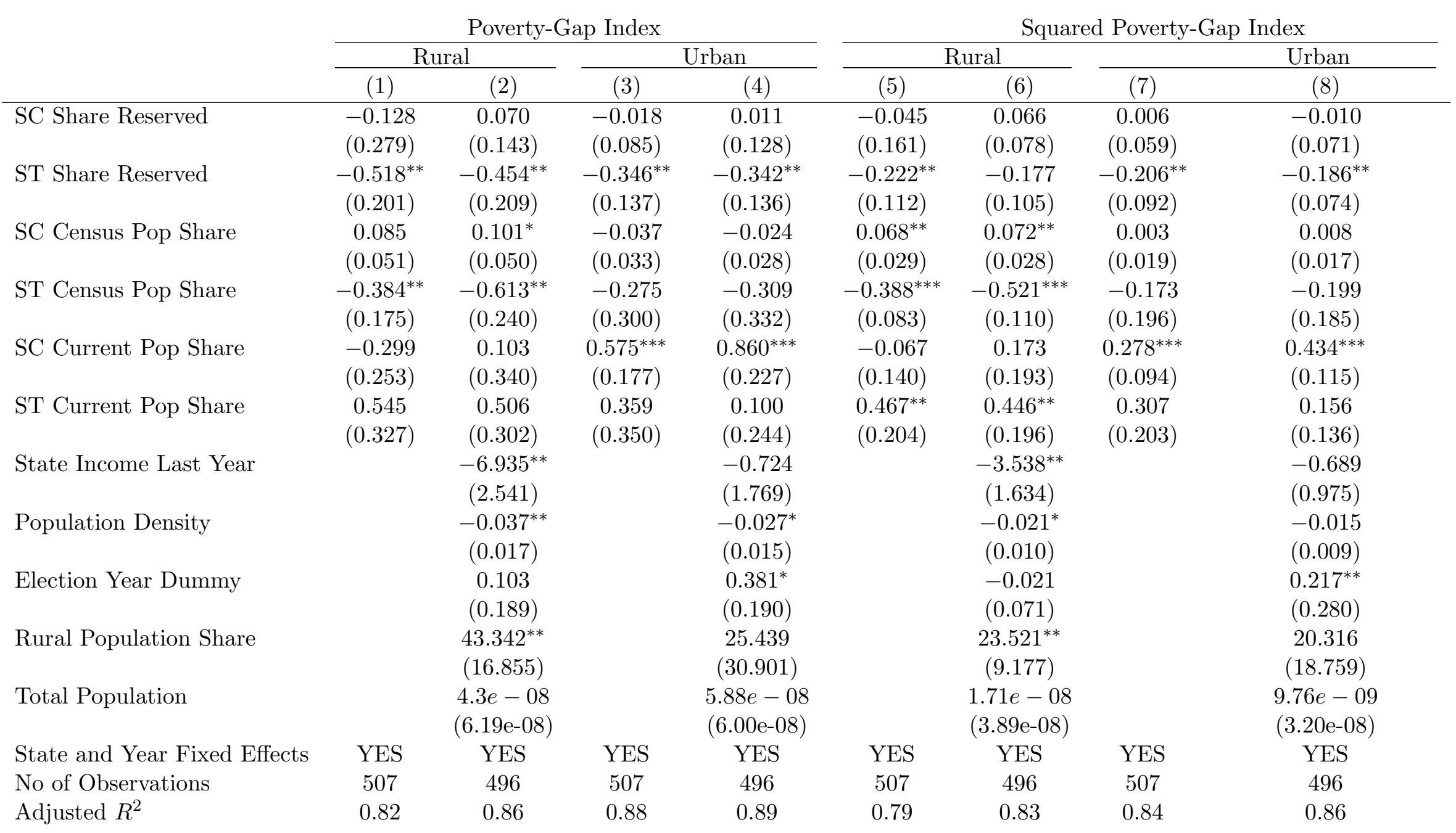

p-value of F-test of equality of effects of SC and ST shares reserved

\begin{tabular}{|c|c|c|c|c|c|c|c|}
\hline$[0.167]$ & {$[0.071]$} & {$[0.047]$} & {$[0.049]$} & {$[0.263]$} & {$[0.105]$} & {$[0.070]$} & {$[0.075]$} \\
\hline
\end{tabular}

Notes: Standard errors clustered by state are in parentheses. "SC(ST) Census Pop Share" is the SC (ST) share of the state population according to the last preceding census. "SC(ST) Current Pop Share" is the SC (ST) share of the state population measured in the current year.

Asterisks denote significance levels $\left(*=.10,{ }^{* *}=.05,{ }^{* * *}=.01\right)$ 
TABLE 5

Robustness Checks

(1)

PANEL A: Rural Headcount Ratio

SC Share Reserved

ST Share Reserved

PANEL B: Urban Headcount Ratio

SC Share Reserved

ST Share Reserved

PANEL C: Aggregate Headcount Ratio

SC Share Reserved

ST Share Reserved
(2)

\begin{tabular}{lllll}
0.077 & 0.007 & 0.089 & 0.399 & 0.273 \\
$(0.284)$ & $(0.270)$ & $(0.272)$ & $(0.341)$ & $(0.301)$ \\
$-1.388^{*}$ & $-1.649^{* * *}$ & $-1.340^{* *}$ & $-1.131^{*}$ & $-1.250^{* *}$ \\
$(0.534)$ & $(0.386)$ & $(0.551)$ & $(0.577)$ & $(0.441)$ \\
& & & & \\
-0.121 & -0.114 & -0.115 & -0.315 & -0.092 \\
$(0.206)$ & $(0.222)$ & $(0.213)$ & $(0.333)$ & $(0.215)$ \\
-0.434 & -0.367 & -0.413 & $-0.590^{*}$ & -0.346 \\
$(0.268)$ & $(0.259)$ & $(0.284)$ & $(0.321)$ & $(0.243)$ \\
& & & & \\
0.063 & 0.007 & 0.072 & 0.321 & 0.226 \\
$(0.217)$ & $(0.211)$ & $(0.210)$ & $(0.280)$ & $(0.225)$ \\
$-1.191^{* *}$ & $-1.399^{* * *}$ & $-1.153^{* *}$ & $-0.999^{*}$ & $-1.090^{* *}$ \\
$(0.486)$ & $(0.360)$ & $(0.503)$ & $(0.533)$ & $(0.398)$ \\
\hline & & & &
\end{tabular}

Notes: Standard errors clustered by state are in parentheses. Results displayed in each panel-column come from a separate regression that also controls for state and time fixed effects, SC and ST population share in the last preceding census, and SC and ST current population share, state income per capita last year, election year dummy, total population, population density in last preceding census and rural population share. The regressions in each column have the following additional features:

Column (1) shows the estimates originally reported in Table 3, Columns 3, 6 and 9.

Column (2) adds as controls the square of SC and ST population shares in the last preceding census.

Column (3) adds as controls the SC and ST population shares one and two years ago.

Column (4) restricts the sample to those observations within a five-year window centered around elections in which the minority political reservation changed in the state.

Column (5) restricts the sample to years when NSS data was available.

The number of observations is 496, 288 and 306 in Columns 1-3, 4 and 5, respectively.

Asterisks denote significance levels $\left(*=.10,{ }^{* *}=.05,{ }^{* * *}=.01\right)$ 